\title{
Development of the antioxidant indexes (FRAP, TFC, TPC) of scabbing resistant apple varieties in storage
}

\author{
Mihály Orosz-Tóth - Sándorné Kincses \\ University of Debrecen, Faculty of Agricultural and Food Sciences and Environmental Management, Institute of Agricultural Chemistry and \\ Soil Science, Debrecen \\ otmisi@gmail.com
}

\section{SUMMARY}

One of the most important groups of bioactive substances in apples are antioxidants, which have a health-preserving effect. The amount of these compounds varies not only during the ripening of the apple fruit, but also continuously during post-harvest storage. A growing group of health-conscious consumers are looking for apple varieties with a nutritional value that satisfies their needs.

In the scope of our research, we examined 5 apple varieties originating from the Derecske horticultural site of KITE cPlc. in 2016. The plantation was planted to be suitable for intensive apple production. Samples were collected at the time of maturity (August-October) of the given variety. The 5 examined apple varieties (Gaia, Isaaq, Modi, Smeralda and Fujion) are all resistant to apple scab (fungal disease caused by Venturia inaequalis). The 2-month storage experiment was conducted at 16-17 ${ }^{\circ} \mathrm{C}$, which had an aggressive effect on our stored apples. Total polyphenol (TPC) and flavonoid (TFC) content as well as FRAP values of the apples were measured. Measurements were taken immediately after harvest and after 1 and 2 months of storage. Our results were evaluated by using the IBM SPSS Statistics 20 software. Our aim was to compare the antioxidant results of 5 scab-resistant apple varieties, which change continuously during storage.

The antioxidant content of our apple varieties increased during 2 months storage. The best result was achieved by the Modi apple variety (FRAP: $467.32 \mathrm{mg} / 100 \mathrm{~g}$; TFC: $317.76 \mathrm{mg} / 100 \mathrm{~g}$; TPC: $1771.97 \mathrm{mg} / 100 \mathrm{~g}$ ). Consumers may want to consume apples stored for a longer period of time if they are to absorb large amounts of antioxidants.

Keywords: apple varieties, antioxidants, storage

\section{INTRODUCTION}

Apples are taxonomically classified as belonging to the Pomoideae subfamily of the Rosaceae family (Borhidi, 1998; Velasco et al., 2010). Domestic apple is a complex hybrid that has evolved over multiple millennia. The cultivated apple is known internationally as Malus ${ }^{\mathrm{x}}$ domestica Borkh (Korban and Skirvin, 1984). Apple production shows a growing tendency in the world. In 1950, 13.5 million tonnes of apples were produced globally, 34.4 million tonnes in 1980 and 69.7 million tonnes in 2010 (O'Rourke, 1994; O'Rourke, 2003; FOASTAT, 2016). This increasing trend can still be observed today, according to data from 2016, total apple production in the world reached 89.33 million tonnes (FAOSTAT, 2016). These enormous amounts can be explained by the generally favourable conditions for apple production (climate, area, processing, storage, market). The most important of the many benefits of apples is that they can be stored for a longer period of time and can therefore be consumed fresh by consumers almost throughout the year (Laczkovszki, 2012). Producers in Hungary also prefer apple varieties that can be stored longer (Idared). Another important aspect when choosing a variety is the resistance of the particular variety against diseases. Taking into account the above, cultivation of resistant varieties may be one of the most efficient and environmentally friendly ways (Jha et al., 2009). It is the common interest of health-conscious consumers and producers to keep less and less chemicals in apple production. For one the parties, it is important to consume healthier food while the otherhas economic reasons (cheaper production costs). The examined apple varieties are resistant to scabbing, which is caused by Venturia inequalis (Cooke, 2000). The fungus infects apples mainly during rainy periods, after which the symptoms appear on the leaves, flowers and fruits of the apple tree.

Everyday apple consumption has a beneficial effect in the treatment of various diseases (diabetes mellitus, metabolic syndrome, celiac disease, inflammatory bowel diseases, colon cancer, etc.) (Scalzo et al., 2005; Blázovics, 2007; Speisky, 2010). This is due to the fact that apple fruits contain numerous biologically active ingredients such as polyphenols, thiols, carotenoids, tocopherols, glucosinolates, flavonoids (querceting glycosides), dihydrocalcones, flavonols, anthocyanins, which contribute to healthy nutrition (Wolfe et al,. 2003; Franciani and Sebastiani, 2013; Ficzek and Tóth, 2013). The amount of these bioactive compounds, including antioxidants, is constantly changing during fruit storage, as apple is a post-ripening fruit. Biosynthetic processes also work in the fruit, but their "storage biological significance is only little known" (Kállay, 2010).

The primary aim of our study was to investigate and compare the antioxidant content (FRAP, TFC and TPC) of 5 Italian scab-resistant apple varieties (Gaia, Isaaq, Modí, Smeralda and Fujion) and their changes during storage.

\section{MATERIALS AND METHODS}

In our experiment, we examined the antioxidant content of the fruit of scab-resistant apple varieties and 
their changes during storage in the year 2016. The 2month storage experiment was set up in the storage of the DE MÉK Institute of Agrochemistry and Soil Science. Storage temperature was $16-7{ }^{\circ} \mathrm{C}$, which accelerated the softening of the apples. Samples were taken three times during storage (immediately after harvesting, after 1 and 2 months) and the total polyphenol (TPC) and total flavonoid content (TFC) of apples and their FRAP antioxidant capacity value was also determined.

\section{Area, plantation data}

In the scope of the experiment, I investigated five apple varieties grown at the Derecske horticultural site of KITE cPlc: Gaia, Isaaq, Modí, Smeralda and Fujion.
Apple trees were planted in 2014 with a support system and hail net. Each apple variety has 6-6 rows, which are $62 \mathrm{~m}$ long. The intensive plantation $(\sim 3000$ trees $\mathrm{ha}^{-1}$ ) is formed on M.9 subject in spindle form. Chemical and mechanical processes are also applied in the plantation.

\section{Soil of the plantation}

The physical nature of the soil is sand and its $\mathrm{pH}$ is slightly acidic and lime-deficient. Based on the humus content, its $\mathrm{N}$-supply is medium, while its $\mathrm{P}$ - and $\mathrm{K}$ supply is very good. (Gonda and Apáti, 2013) Table 1 shows the most important physical and chemical properties of soil.

The most important physicochemical properties of the soil of the plantation

\begin{tabular}{ccccccccc}
\hline Depth [cm] & $\mathrm{K}_{\mathrm{A}}$ & Humus [m/m\%] & $\begin{array}{c}\mathrm{AL}^{-\mathrm{P}_{2} \mathrm{O}_{5}} \\
{\left[\mathrm{mg} \mathrm{kg}^{-1}\right]}\end{array}$ & $\begin{array}{c}\mathrm{AL}-\mathrm{K}_{2} \mathrm{O} \\
{\left[\mathrm{mg} \mathrm{kg}^{-1}\right]}\end{array}$ & lime $[\mathrm{m} / \mathrm{m} \%]$ & $\mathrm{y}_{1}$ & $\mathrm{pH}_{\mathrm{KCl}}$ & $\mathrm{pH}_{\mathrm{H} 2 \mathrm{O}}$ \\
\hline $0-20$ & 25 & 0.9 & 281 & 330 & $<0.1$ & 8.8 & 5.50 & 6.51 \\
$20-40$ & 25 & 0.9 & 325 & 308 & $<0.1$ & 10.3 & 5.26 & 6.27 \\
$40-60$ & 25 & 0.7 & 85 & 187 & $<0.1$ & 12.0 & 4.45 & 5.63 \\
\hline
\end{tabular}

$\mathrm{K}_{\mathrm{A}}$ : the amount of water taken up by soil to reach plasticity capacity $\left(\mathrm{cm}^{3} / 100 \mathrm{~g}\right)$; AL: ammonium lactate soluble (Egnér et al., 1960)

\section{Nutrient supply}

The soil is slightly acidic and therefore the micronutrient supply was solved by foliar fertilization. The following table (Table 2) shows the nutrient supply program:

Nutrient supply program

\begin{tabular}{|c|c|c|c|c|}
\hline & \multirow[t]{2}{*}{ Distribution } & \multicolumn{3}{|c|}{ Fertilization requirement $\left(\mathrm{kg} \mathrm{ha}^{-1}\right)$} \\
\hline & & calcium-nitrate & ammonium-nitrate & monopotassium phosphate \\
\hline 1 week after flowering & $2 x$ & 56 & & 78 \\
\hline After fruit set & $2 \mathrm{x}$ & 56 & & 24 \\
\hline $\begin{array}{l}\text { Fruit growth } \\
\text { (only until the middle of July) }\end{array}$ & $6 x$ & 169 & & 71 \\
\hline Autumn & $1 \mathrm{x}$ & & 32 & \\
\hline
\end{tabular}

The amount of fertilizer ingredients applied: $\mathrm{N}=53.44\left(\mathrm{~kg} \mathrm{ha}^{-1}\right), \mathrm{P}=34.43\left(\mathrm{~kg} \mathrm{ha}^{-1}\right), \mathrm{K}=49.61\left(\mathrm{~kg} \mathrm{ha}^{-1}\right), \mathrm{Ca}=68.54\left(\mathrm{~kg} \mathrm{ha}^{-1}\right)$

\section{Meteorological factors}

Annual precipitation amounts, temperatures (average, maximum, minimum) and the number of sunny hours at the Derecske horticultural site of KITE cPlc. are summarized in Table 3. According to multiple years of climate data in Hungary, heavy rainfall fell in 2016 , but the number of sunny hours was lower.

Temperature, precipitation and the number of sunny hours (Derecske)

\begin{tabular}{lcccccccccccc}
\hline & \multicolumn{1}{c}{ Derecske horticultural site of KITE cPlc. $(2016)$} & \multicolumn{1}{c}{} \\
Measurement months & Jan. & Feb. & Mar. & Apr. & May & Jun. & Jul. & Aug. & Sep. & Oct. & Nov. & Dec. \\
\hline Minimum temperature $\left({ }^{\circ} \mathrm{C}\right)$ & -16.6 & -3.8 & -4.6 & -0.5 & 3.9 & 10.5 & 10.7 & 9.1 & 4.4 & 0.3 & -3.6 & -10 \\
Maximum temperature $\left({ }^{\circ} \mathrm{C}\right)$ & 10.4 & 16.1 & 21.2 & 25.9 & 28.9 & 34.1 & 32.7 & 32.1 & 30.9 & 24.8 & 17.8 & 8.3 \\
Mean temperature $\left({ }^{\circ} \mathrm{C}\right)$ & -1.8 & 5.9 & 6.8 & 13 & 16.4 & 20.8 & 21.7 & 20.6 & 17.9 & 9.5 & 9.5 & 4.4 \\
Precipitation amount $(\mathrm{mm})$ & 67 & 97 & 32 & 8 & 49 & 127 & 106 & 91 & 43 & 73 & 49 & 2 \\
Number of sunny hours & 49 & 69 & 166 & 237 & 318 & 297 & 340 & 329 & 254 & 123 & 101 & 90 \\
\hline
\end{tabular}




\section{Sampling, measurements}

Samples were collected in 2016 according to the ripening time of the given varieties; $4-5 \mathrm{~kg}$ of fruit was collected from every $2-2$ rows. The examinations were performed in 6 replicates. 5-5 apples were randomly selected from the harvested samples, and following appropriate preparation, the various antioxidant indexes (FRAP, TFC, TPC) were measured after harvesting and after storage. Measurements were taken immediately after harvest and after 1 and 2 months of storage.

Table 4

Sampling dates

\begin{tabular}{llllll}
\hline & Gaia & Isaaq & Modí & Smeralda & Fujion \\
\hline 2016 & 08.29 & 09.09 & 09.09 & 10.13 & 10.27 \\
\hline
\end{tabular}

\section{Determination of antioxidant contents}

Apple samples were homogenized and made into methanol solutions with 80:20 ratio (methanol: distilled water). Using the methanol extract, total polyphenol content, total flavonoid content and FRAP values of apples were measured.

\section{Determination of the total polyphenol content}

Determination of the total polyphenol content is based on the fact that phenolic substances reduce the mixture of phosphorus molybdenum and phosphorus tungstic acid in a basic medium. The reduction produces blue molybdenum and tungsten oxides. The higher the colour intensity, the higher the proportion of phenolic compounds. To the methanolic extracts, Folin-Ciotalteau reagent and sodium carbonate solution were added and the absorbance of the solutions was measured at $760 \mathrm{~nm}$ using a spectrophotometer (Metertek SP-850). The polyphenol content of the samples was expressed as mg GAE (gallic acid equivalent)/100g dry product. (Huang et al., 2005)

\section{Determination of the total flavonoid content}

Sodium nitrite, aluminium chloride and sodium hydroxide were added to the methanol extracts prepared from the samples, and their colour intensity was measured at $510 \mathrm{~nm}$ using a spectrophotometer (Metertek SP-850). Results are expressed as mg CAE (catechin equivalent)/100 g dry product. (Kim et al., 2003)

\section{Determination of the FRAP value}

The FRAP (Ferric Reducing Ability of Plasma) method is based on the fact that antioxidants reduce $\mathrm{Fe}^{3+}$ (ferri) ions to $\mathrm{Fe}^{2+}$ (ferro) ions, which at low $\mathrm{pH}$ form ferro-tripyridyltriazine (blue complex)with tripyridyltriazine $(\mathrm{TPTZ}=2.4 .6$ tripyridyl-S-triazine) . For conducting the measurement, we needed FRAP reagent (acetate buffer $+\mathrm{FeCl}_{3}$ solution+TPTZ solution), which was added to the methanol extracts. The prepared mixtures were measured photometrically at $593 \mathrm{~nm}$. Results are expressed as mg ASA (ascorbic acid equivalent)/100g dry matter. (Benzie and Strain, 1996)

\section{Statistics}

The measured data were recorded in the MS Excel spreadsheet software. For single-factor analysis of variance, IBM SPSS Statistics 20 was used. 'One-Way ANOVA'- Tukey's test was used between apple varieties/variety and the incubation periods for analysis. Signals from the SPSS software are shown in the figures below.

\section{RESULTS AND DISCUSSION}

Figure 1 shows the FRAP values of apple varieties concerning 2 months of storage. The figure shows that the values of two apple varieties (Gaia and Modí) are the highest on all three measurement dates. The lowest values were provided by Isaaq and Smeralda. According to the figure, our apple varieties statistically divided into 2 groups on the first measurement date, Gaia and Modí belonged to one group, while Isaaq, Smeralda and Fujion belonged to the other group. The different varieties of apples had statistically proven to have more or less antioxidant capacity. After a month, these groups changed and our apple varieties were classified into 3 groups. Modí had a significantly higher Frap value $(368.47 \mathrm{mg} / 100 \mathrm{~g})$ than other apple varieties. On the final measurement date, our data already formed 4 sets; Frap values of the apple varieties showed statistically significant differences. From the above results it can be concluded that the dynamics of changes in apple varieties during storage were different.

Table 5 shows the change and statistical evaluation of FRAP values during storage. Our results represent that the antioxidant content of all apple varieties increased during 2 months storage. Significant increases were observed in all measurements for the Modí variety, but for each scab-resistant apple variety, measurements 1 and 3 were found to be in different data sets, so the increase of Frap values is statistically confirmed.

Figure 2 shows the total flavonoid content (TFC) of apple varieties for dry matter content. Here, as in the case of FRAP values, Gaia and Modí had the highest TFC values. During 2 months of storage, TFC results showed steady growth in all apple varieties. The lowest value $(30.64 \mathrm{mg} / 100 \mathrm{~g})$ and the smallest change were shown by the Isaaq variety. According to the results of the $1^{\text {st }}$ measurement, our apple varieties can be classified into three groups by the TFC results, while in the $2^{\text {nd }}$ and $3^{\text {rd }}$ measurements, there are 4 groups. Gaia and Modí represent separate groups. The results of Smeralda and Fujion are almost identical. 
Figure 1: The FRAP value of apple varieties during storage

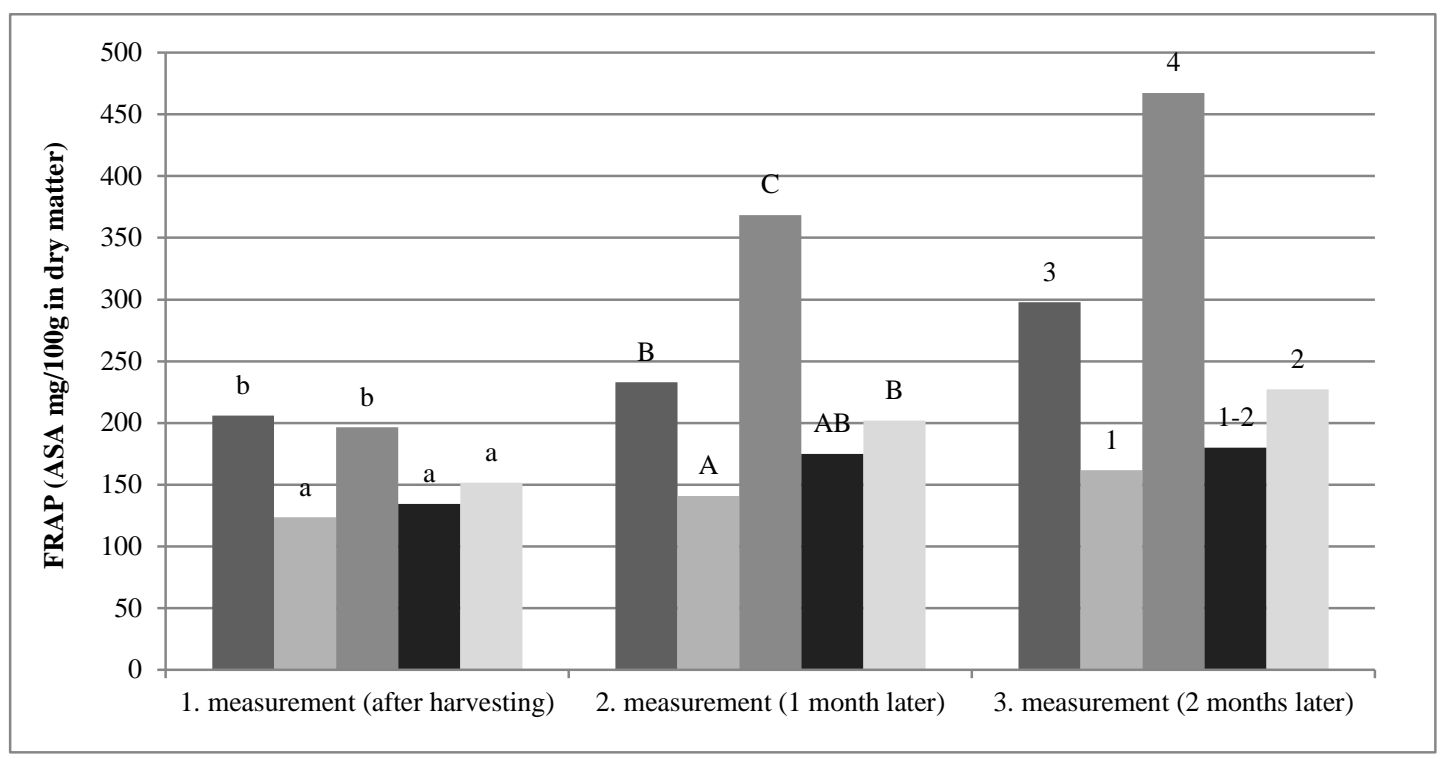

Note: result of 1 . measurement has been marked with small letters, 2 . measurement has been marked with big letters, 3 . measurement has been marked with numbers.

FRAP values between some examined variety and incubation periods (ASA mg/100g in dry matter)

\begin{tabular}{lccccc}
\hline & Gaia & Isaaq & Modí & Smeralda & Fujion \\
\hline 1. measurement (after harvesting) & $205.84 \mathrm{a}$ & $123.58 \mathrm{a}$ & $196.46 \mathrm{a}$ & $134.34 \mathrm{a}$ & $151.69 \mathrm{a}$ \\
2. measurement (1 month later) & $233.09 \mathrm{ab}$ & $140.93 \mathrm{ab}$ & $368.47 \mathrm{~b}$ & $175.04 \mathrm{~b}$ & $201.73 \mathrm{~b}$ \\
3. measurement (2 months later) & $297.83 \mathrm{~b}$ & $161.69 \mathrm{~b}$ & $467.32 \mathrm{c}$ & $180.1 \mathrm{~b}$ & $227.3 \mathrm{~b}$ \\
\hline
\end{tabular}

Means with the different letters in each column indicate significant differences at $\mathrm{p} \leq 0.05$ (level of probability) between incubation periods.

Figure 2: TFC value of apple varieties during storage

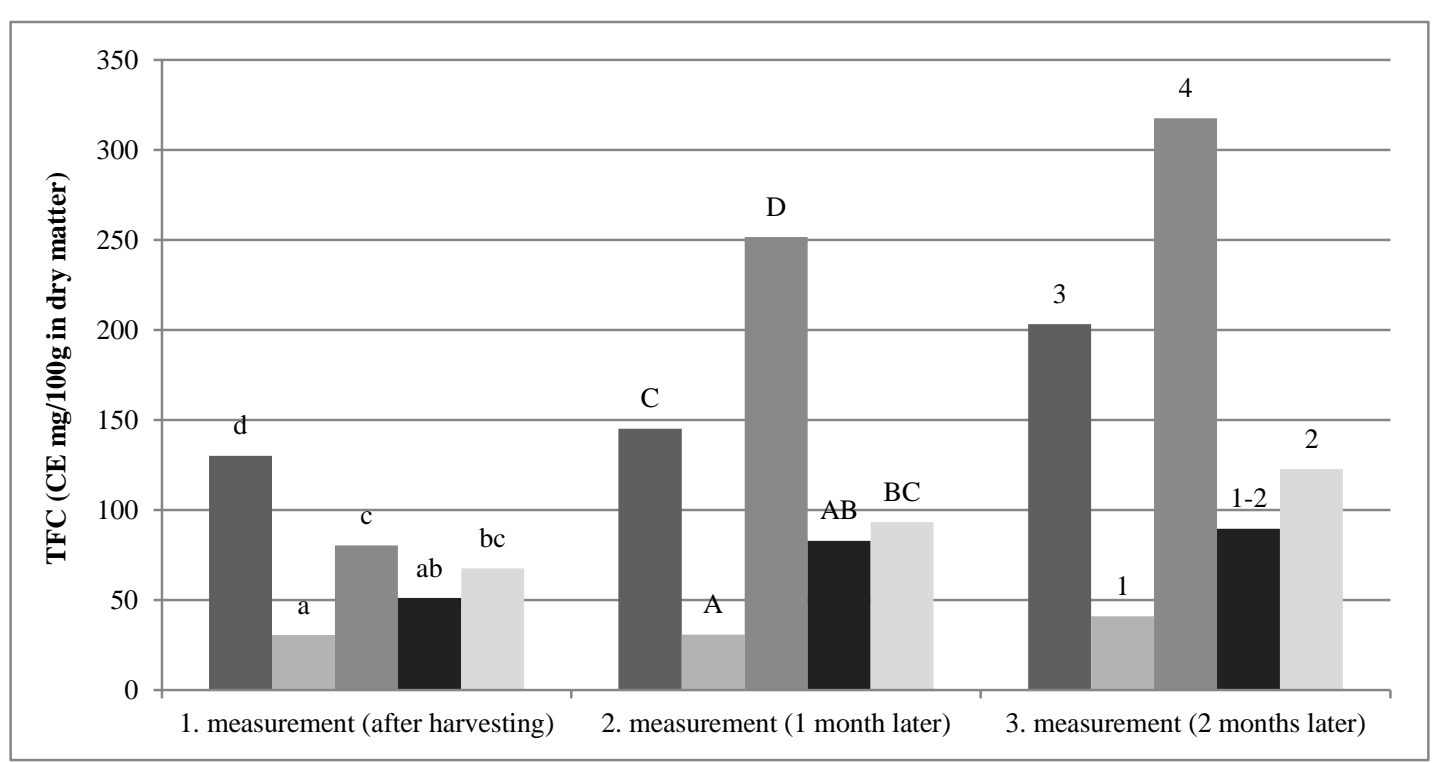

Note: result of 1. measurement has been marked with small letters, 2. measurement has been marked with big letters, 3. measurement has been marked with numbers. 
TFC values between some examined variety and incubation periods (CE mg/100g in dry matter)

\begin{tabular}{lccccc}
\hline & Gaia & Isaaq & Modí & Smeralda & Fujion \\
\hline 1. measurement (after harvesting) & $130.29 \mathrm{a}$ & $30.64 \mathrm{a}$ & $80.47 \mathrm{a}$ & $51.18 \mathrm{a}$ & $67.76 \mathrm{a}$ \\
2. measurement (1 month later) & $145.13 \mathrm{a}$ & $30.78 \mathrm{a}$ & $251.67 \mathrm{~b}$ & $82.95 \mathrm{~b}$ & $93.46 \mathrm{~b}$ \\
3. measurement (2 months later) & $203.23 \mathrm{~b}$ & $41.12 \mathrm{a}$ & $317.76 \mathrm{~b}$ & $89.62 \mathrm{~b}$ & $122.71 \mathrm{c}$ \\
\hline
\end{tabular}

Means with the different letters in each column indicate significant differences at $\mathrm{p} \leq 0.05$ (level of probability) between incubation periods

Table 6 shows the change and statistical evaluation of TFC values during storage. Generally, all apple varieties included in the study showed a statistically confirmed increase in TFC over 2 months of storage. Among the five apple varieties, the values of Fujion measured on three dates showed a statistically confirmed increase. For the rest of the apple varieties there is a significant difference between the $1^{\text {st }}$ and $3^{\text {rd }}$ measurements. The highest value during storage was achieved by the Modí variety $(317.76 \mathrm{mg} / 100 \mathrm{~g})$.

Figure 3 shows the measured results (TPC) of the total polyphenol content of our apple samples. According to our data, TPC results are the highest among the three examined indexes. Modí showed outstanding TPC results, but the total polyphenol content of Gaia was also significant. The lowest value was measured in the case of Isaaq. TPC also showed an upward trend as the storage time progressed. On each of the three measurement dates, TPC results of apple varieties were classified into 3-3 groups. Results of Modi were statistically different from the other apple varieties on each of the three measurement dates. The results of Isaaq, Smeralda and Fujion differed less from each other.

Table 7 separately shows the TPC antioxidant content of each apple species, which increased gradually over two months of storage. We were able to present a significant difference among the measurements in the case of the Modi variety, but it is visible for all apple varieties that measurements 1 and 3 are in different data sets, therefore their results show a significant increase.

Figure 3: The TPC value of the apple varieties during storage

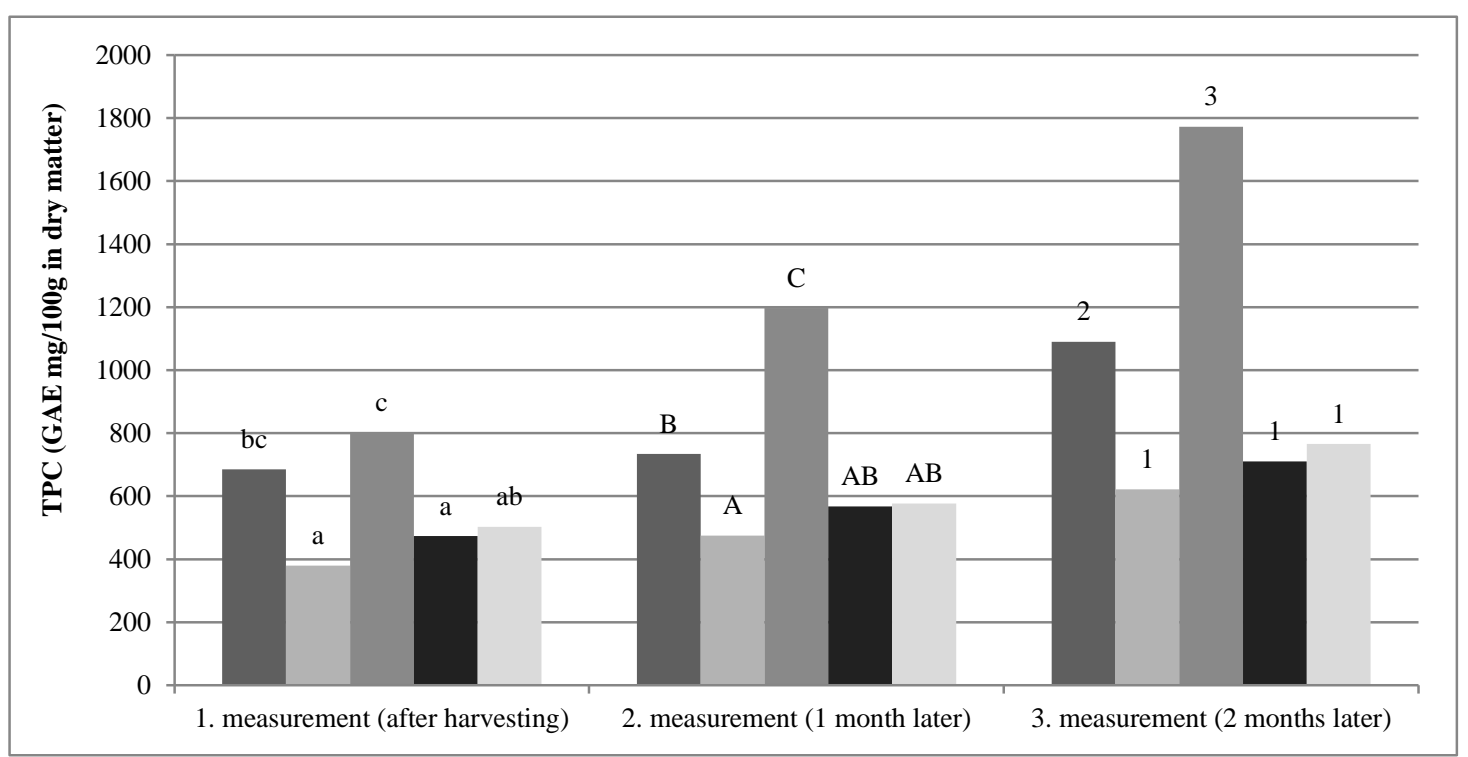

Note: result of 1. measurement has been marked with small letters, 2. measurement has been marked with big letters, 3. measurement has been marked with numbers.

TPC values between some examined variety and incubation periods (GAE mg/100g in dry matter)

\begin{tabular}{lccccc}
\hline & Gaia & Isaaq & Modí & Smeralda & Fujion \\
\hline 1. measurement (after harvesting) & $685.48 \mathrm{a}$ & $380.20 \mathrm{a}$ & $802.87 \mathrm{a}$ & $473.39 \mathrm{a}$ & $502.64 \mathrm{a}$ \\
2. measurement (1 month later) & $733.57 \mathrm{a}$ & $474.35 \mathrm{a}$ & $1197.19 \mathrm{~b}$ & $568.09 \mathrm{a}$ & $577.36 \mathrm{a}$ \\
3. measurement (2 months later) & $1090.12 \mathrm{~b}$ & $622.09 \mathrm{~b}$ & $1771.97 \mathrm{c}$ & $710.67 \mathrm{~b}$ & $765.50 \mathrm{~b}$ \\
\hline
\end{tabular}

Means with the different letters in each column indicate significant differences at $\mathrm{p} \leq 0.05$ (level of probability) between incubation periods 


\section{CONCLUSION}

Evaluating our results it can be said that the measured antioxidant levels increased in our apple varieties during storage under the conditions set by us. Their initial results and antioxidant growth during storage were different for the five apple varieties. Our results suggest that during storage, antioxidant compounds are formed in the fruit even during the postripening phase. During storage of the fruit, the increased levels of antioxidants are also attributable to the too intensive softened flesh, the structure of cell walls and cell membranes was modified, and the fibrerestricted (pectin) antioxidant content, became more extractable by solvents.

Through the consumption of fresh fruits, a large amount of antioxidants can be introduced into the human body. Part of the intestinal antioxidant content is limited in terms of absorption due to the high fibre content in the fruits (which also acts as a physical barrier and speeds up gastrointestinal tract function). In our opinion, in the case of post-ripening fruits and apple, after harvesting leaving enough time for the ripening/maturation processes can positively influence the amount and absorption of antioxidants in the fruit.

Out of the five examined scab resistant apple varieties, Modi is the most recommended based on its antioxidant content. Gaia is less suitable for long-term storage, as this variety has been bred for immediate fresh consumption, which means greater economic loss in the case of storage and its enjoyment value is minimized for consumers after long storage. Modí will continue to have sufficient consumption quality even after longer storage.

Further storage studies will be required in the future to provide more information on these five scabresistant apple varieties.

\section{REFERENCES}

Benzie, F. F.-Strain, J. J. (1996): The Ferric Reducing Ability of Plasma (FRAP) as a Measure of „Antioxidant Power”; The FRAP Assay. Analytical biochemistry. 239: 70-76.

Blázovics, A. (2007): Coeliakia Konszenzus Konferencia, beszámoló Magyar Belorvosi Archivum. 315-317.

Borhidi, A. (1998): Nevezéktani korrekciók és egyéb kiegészítések a Magyarországi Edényes Flóra Határozójához- Kitaibelia.

Egnér, H.-Riehm, H.-Domingo, W. R. (1960): Untersuchungen über die chemische Bodenanalyseals Grundlage für die Beurteilung de.

FAOSTAT (2016): Food and Agriculture Organization of the United Nations.: www.fao.org/faostat/en/\#data/QC

Ficzek, G.-Tóth, M. (2013): A gyümölcsök beltartalmi anyagai. In: Tóth, M. (szerk.): Magyarország kultúrflórája- Az alma. Agroinform Kiadó, Budapest, 190.

Francini, A.-Sebastiani, L. (2013): Phenolic Compoundsin Apple (Malus x domestica Borkh.): Compounds Characterization and StabilityduringPostharvest and afterProcessing." Antioxidants 2, no. 3: 181-193.

Gonda, I.-Apáti, F. (2013): Versenyképes almatermesztés. Szaktudás Kiadó Ház Zrt., Budapest. 31., 134-144.

Huang, D. J.-Ou, B. X.-Prior, R. L. (2005): The chemistry behind antioxidant capacity assays. Journal of Agricultural and Food Chemistry, (53):1841-1856.

Jha, G.-Thakur, K.-Thakur, P. (2009): The Venturia Apple Pathosystem: Pathogenicity Mechanisms and Plant Defense Responses. Journal of Biomedicine and Biotechnology, 2009, 680160. http://doi.org/10.1155/2009/680160

Kállay, T. (2010): Az almatárolás biológiája. Mezőgazda Kiadó. Budapest, 7-31.
Kim, D. O.-Jeong, S. W.-LEE, C. Y. (2003): Antioxidant capacity of phenolic phytochemicals from various cultivars of plums. Food Chemistry, 81. 321-326.

Korban, S. S.-Skirvin, R. M. (1984): Nomenclature of the cultivated apple. HortScience 19: 177-180.

Laczkovszki, Cs. (2012): Gyümölcstermesztés. Magyar Agrárkamara, Budapest. 1-238. p. ISBN 9786155307065.

Nährstoffzustandes der Böden. II. K. LantbrHögsk. Ann. 26: 199215.

O'Rourke, A. D. (1994): The world apple market. Food Products Press, New York.

O'Rourke, D. (2003): World production, trade, consumption and economic outlook for apples. 15-29. in: Ferree, D. C.Warrington, I. J. (eds.): Apples. Botany, production and uses. CABI Publishing, Cambridge.

Scalzo, J.- Politi, A.- Pellegrini, N.-Mezetti, B.-Battino, M. (2005): Plant genotype affects total antioxidant capacity and phenolic contents in fruit. Nutrition 207-213.

Speisky, H. (2010): Determination of antioxidant capacity, total phenolic content and mineral composition of different fruit tissue of five apple cultivars grown in Chile. Chil. J. Agric. Res. p. 523536.

Velasco, R.-Zharkikh, A.-Affourtit, J.-Dhingra, A.-Cestaro, A.Kalyanaraman, A. (2010): The genome of the domesticated apple (Malus $\times$ domestica Borkh.). Nat. Genet. 42, 833-839. doi: $10.1038 /$ ng.654

Wolfe, K.-Wu, X.- Liu, R. H. (2003): Antioxidant activity of apple peels. J. Agric. Food Chem. 51. 609-614. 